\title{
PELATIHAN PEMBERDAYAAN KELOMPOK WANITA PEMBUAT KERUPUK UBI UNGU DI DESA PADAHANTEN
}

\author{
Whydiantoro*, Budiman, Engkos Koswara \\ Universitas Majalengka, Indonesia \\ *why@unma.ac.id
}

\begin{abstract}
The purple sweet potato cracker product is the result of the creativity of the women's farmer group in Padahanten village. Until now, purple sweet potato crackers have not been able to become the main commodity in helping the economy of the women farmer group. Only a few members sell crackers. However, in practice sales are so small that they cannot be used as a reliable source of income. This is caused by various factors, one of the contributing factors is product packaging and product marketing. Product packaging currently only uses simple plastic without using a brand or logo, so it is less attractive to consumers. For marketing only through local residents and stalls in the village. In the manufacturing process, women farmer groups have not used tools/machines to speed up the production process. So it takes a relatively long time to produce crackers. In this community service activity, the packaging design will be made to the manufacture of marketing media in the form of web marketing. With this is expected to increase consumer interest and marketing. In addition, the manufacture of production equipment and training will be given to the women's farmer group in Padahanten Village in order to increase the production speed of the purple sweet potato cracker product.
\end{abstract}

Keywords: Purple Sweet Potato Crackers; Product Packaging; Web Marketing; Production Tools/machines.

\begin{abstract}
Abstrak
Produk kerupuk ubi ungu merupakan hasil kreativitas dari kelompok wanita tani desa padahanten. Sampai saat ini, kerupuk ubi ungu belum mampu menjadi komoditas utama dalam membantu perekonomian kelompok wanita tani tersebut. Hanya beberapa anggota yang menjual kerupuk. Akan tetapi, dalam prakteknya penjualan tidak seberapa hingga tidak dapat dijadikan sumber penghasilan yang dapat diandalkan. Hal tersebut diakibatkan dari berbagai faktor, salah satu faktor penyebabnya adalah kemasan produk dan pemasaran produk. Kemasan produk saat ini hanya menggunakan plastik sederhana tanpa menggunakan merk ataupun logo, sehingga kurang menarik minat konsumen. Untuk pemasaran hanya melalui warga sekitar dan warung-warung di desa tersebut. Dalah proses pembuatannya, kelompok wanita tani belum menggunakan alat/mesin untuk mempercepat proses produksi. Sehingga untuk menghasilkan produk kerupuk memerlukan waktu yang relatif sangat lama. Dalam kegiatan pengabdian kepada masyarakat ini, akan dilakukan pembuatan desain kemasan hingga pembuatan media pemasaran berupa web pemasaran. Dengan hal tersebut diharapkan dapat meningkatkan minat konsumen dan pemasaran. Selain itu, pembuatan alat produksi beserta pelatihannya akan diberikan kepada kelompok wanita tani Desa Padahanten supaya dapat meningkatkan kecepatan produksi dari produk kerupuk ubi ungu tersebut.
\end{abstract}

Kata Kunci: Kerupuk Ubi Ungu; Kemasan Produk; Web Pemasaran; Alat/mesin Produksi.

\begin{tabular}{l|l|l} 
Submitted: $2021-06-26$ & Revised: 2021-07-25 & Accepted: 2021-07-31
\end{tabular}

\section{Pendahuluan}

Desa padahanten merupakan salah satu desa yang berada di wilayah kabupaten Majalengka, dimana daerah tersebut mempunyai komoditas utama dibidang pertanian. Salah satu yang menjadi andalannya adalah Ubi. Sampai saat ini, ubi hanya dijual ke pengepul.

Kelompok ibu-ibu rumah tangga membuat sebuah inovasi dalam produk ubi. Kelompok tersebut menjadikan ubi ungu sebagai bahan baku Kerupuk. Produk ini hampir tiap rumah, khususnya warga blok rabu desa padahanten membuat produk kerupuk ubi ungu.

Dalam proses pembuatannya masih mengandalkan alat seadanya, sehingga pembuatan produk tersebut memakan waktu cukup lama. Gambar 1 menunjukan bagaimana proses pembuatan kerupuk yang terjadi di kelompok wanita tani desa padahanten, masih menggunakan alat sederhana tanpa adanya bantuan alat untuk memaksimalkan hasil produk. 

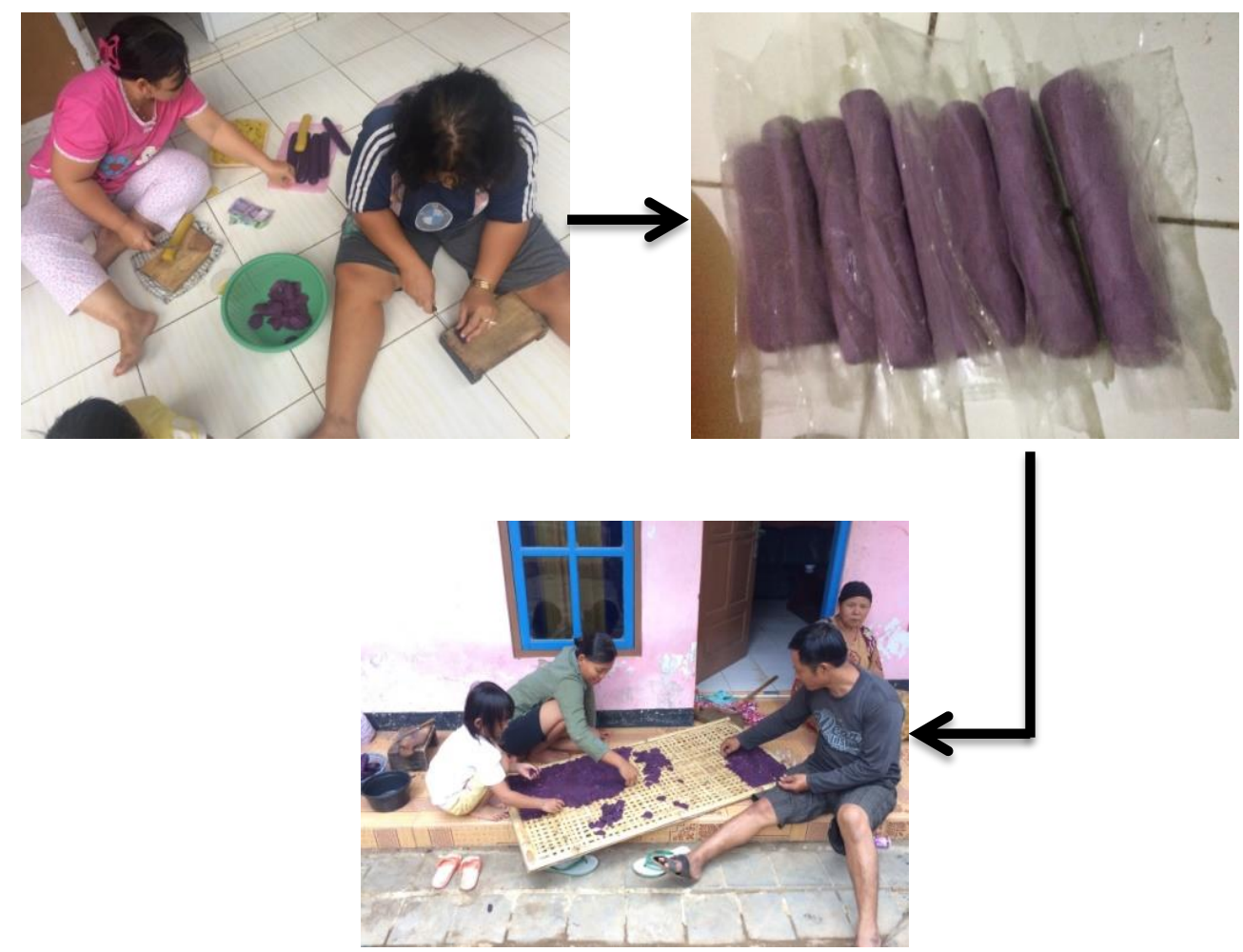

Gambar 1. Proses pembuatan kerupuk ubi ungu

Selain itu, produk kerupuk ubi ini belum dijadikan sebagai produk pasar, hanya ada beberapa warga saja yang memasarkan produk ubi ini, meskipun pemasaran masih dilakukan di desa padahanten sendiri. Gambar 2 menunjukan bagaimana kelompok wanita tani desa padahanten melakukan pengemasan pada produk hasil olahan tersebut.

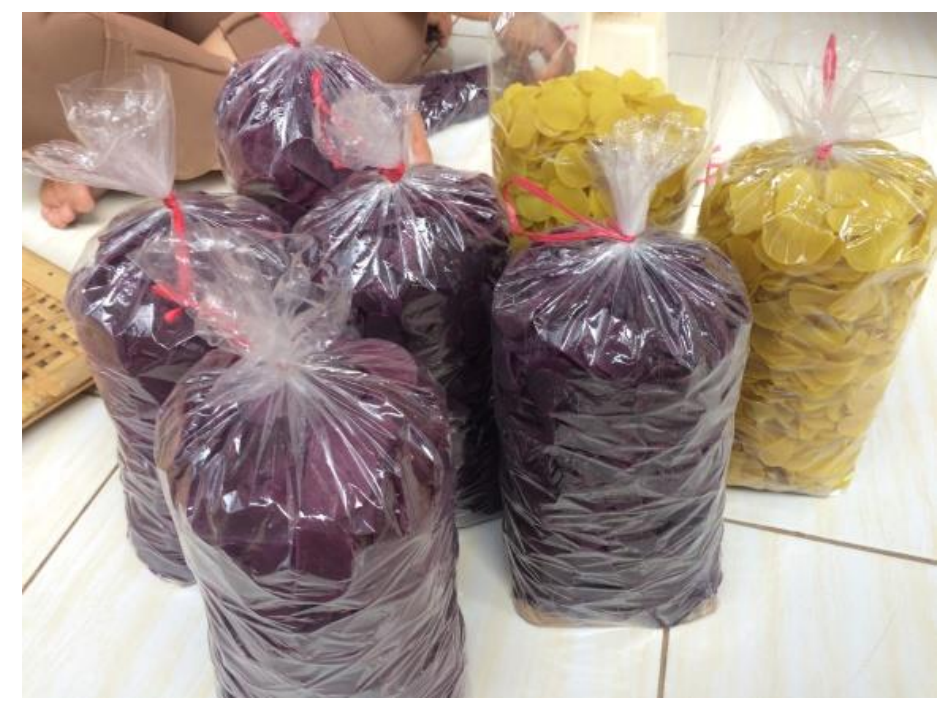

Gambar 2. Pengemasan pada produk hasil olahan

\section{Metode}

Metode dan Tahapan Pengabdian yang akan dilaksanakan adalah sebagai berikut :

a. Tahapan persiapan

Pada tahapan persiapan, tim melakukan survey lapangan terhadap tempat produksi kerupuk ubi ungu yang akan menjadi objek/mitra pengabdian. 
b. Pelaksanaan

- Survey lapangan dan Sosialisasi Pelatihan Pemasaran produk UMKM

Kegiatan ini ditujukan untuk memberikan gambaran umum tentang program Pelatihan Pemasaran produk UMKM hingga pengelolaan pada kelompok masyarakat. Pada tahap ini juga, merupakan evaluasi awal untuk melihat respon masyarakat terhadap program yang akan dijalankan.

- Studi literature

Pada tahap ini, peneliti mempelajari kebutuhan akan teori yang menunjang akan terlaksananya proses pengabdian.

- Identifikasi kebutuhan

Penentuan kebutuhan dalam pengabdian perlu dilakukan, supaya proses pengabdian ini tepat sasaan.

- Perencanaan desain kemasan

Pembuatan desain kemasan sebagai penunjang keberlangsungan proses pemasaran diharapkan dapat meningkatkan minat konsumen

- Perencanaan teknologi pendukung produksi

Alat/mesin produksi akan diberikan dan disesuaikan dengan kebutuhan beserta pelatihan terhadap pengguna (kelompok wanita tani desa padahanten)

- Perencanaan web pemasaran

Pembuatan Web pemasaran digunakan sebagai sarana penunjang untuk pemasaran.

\section{Hasil dan Pembahasan}

1. Tahapan persiapan

Pada tahapan ini, kami melakukan survey langsung ke tempat produksi kerupuk ubi ungu yang berada di Blok Rabu Desa Padahanten Kecamatan Sukahaji Kabupaten Majalengka - Jawa Barat. Dalam proses pembuatannya, warga menggunakan cara tradisional tanpa adanya alat bantu untuk mempermudah ataupun mempercepat proses produksi. Dimulai dari pengupasan ubi ungu hingga penjemuran/penggorengan kerupuk.

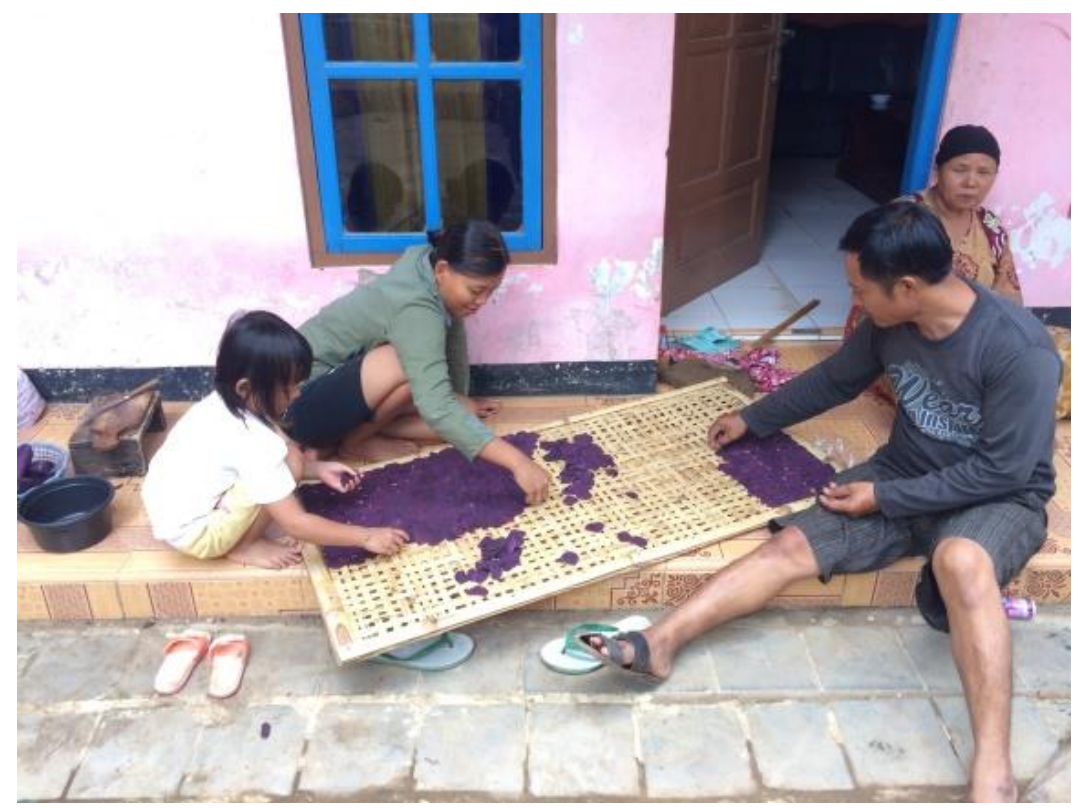

Gambar 3. Proses penjemuran kerupuk ubi ungu

2. Sosialisai program 
Pada tahapan ini, kami melakukan sosialisasi program yang akan dilaksanakan terhadap mitra pengabdian. Program yang akan dilakukan diantaranya pelatihan desain kemasan supaya lebih menarik dan pelatihan pemasaran via online, salah satunya membantu pembuatan website untuk pemasaran produk kerupuk ubi ungu.

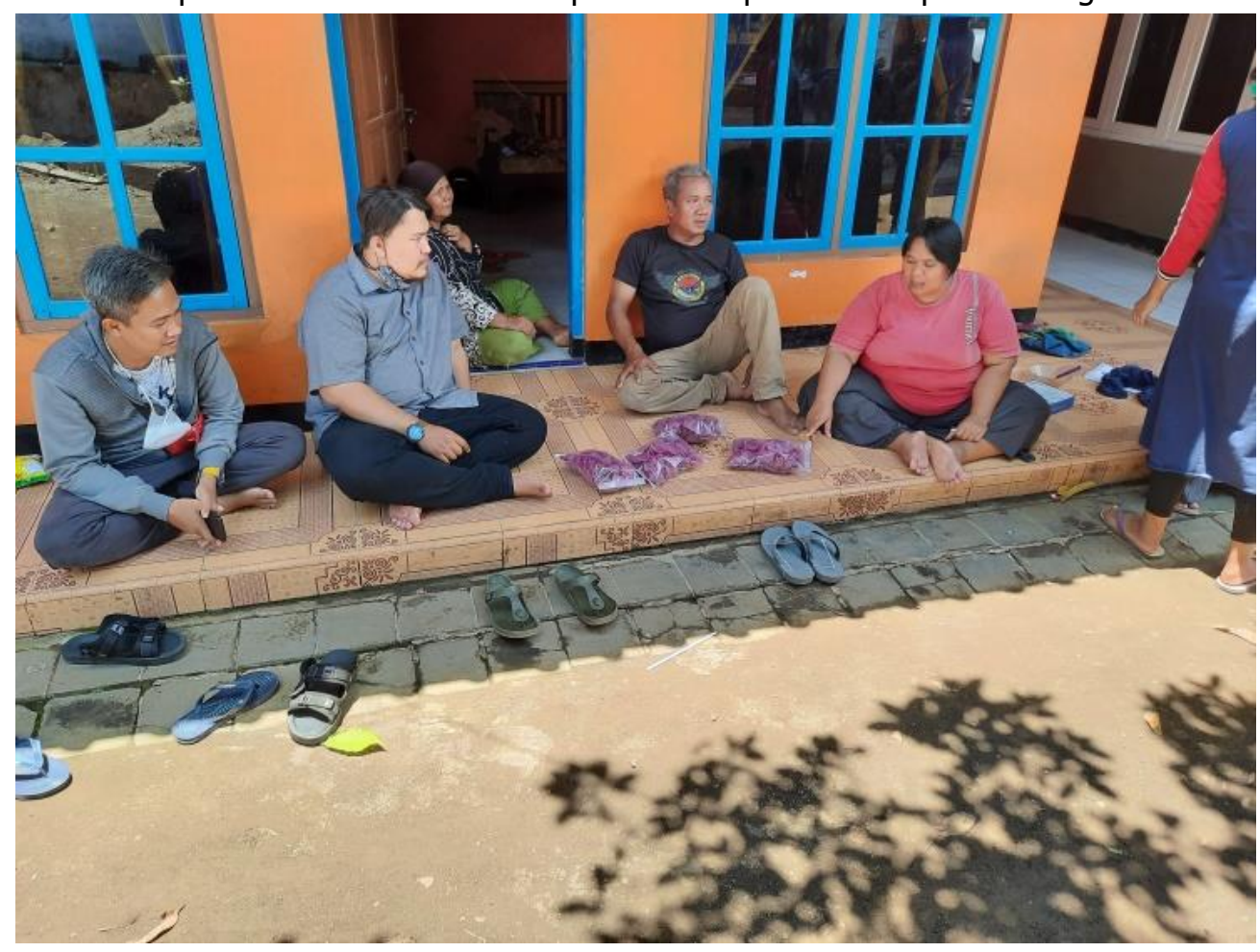

Gambar 4. Sosialisasi Program Pengabdian Masyarakat kepada Kelompok Wanita pembuat Kerupuk Ubi Ungu

3. Identifikasi kebutuhan

Hasil dari sosialisasi program Pengabdian, terdapat beberapa kebutuhan kelompok wanita tersebut. Kebutuhan tersebut ditujukan untuk menunjang produksi dari kerupuk ubi ungu hingga pemasaran yang masih mencakup daerah sekitar. Kebutuhan tersebut diantarnya alat/mesin pembuat adonan kerupuk, alat/mesin pemotong kerupuk, alat pengering kerupuk mentah, kemasan yang lebih menarik hingga bantuan pemasaran.

Alat/mesin pembuat adonan dimaksudkan untuk mengaduk adonan ubi yang sudah dikukus terlebih dahulu dicampur dengan bahan - bahan lainnya. Saat ini, yang dilakukan hanya menggunakan bantuan tangan dan dibantu dengan wadah seadanya hingga proses pengadukan pun membutuhkan waktu yang cukup lama. Dengan alat/mesin tersebut kelompok berharap dapat meningkatkan jumlah produksi.

Alat/mesin pemotong adonan kerupuk ditujukan untuk memotong adonan kerupuk yang telah siap dipotong. Saat ini, pemotongan kerupuk masih menggunakan pisau saja. Dengan seperti itu, proses pemotongan membutuhkan waktu yang cukup lama dan bentuk potongannya pun tidak seragam. Dengan alat/mesin tersebut diharapkan dapat mempercepat proses pemotongan kerupuk dan bentuk kerupuk lebih seragam.

Alat/mesin pengering kerupuk ditujukan untuk mengeringkan kerupuk yang telah melalui proses pemotongan. Saat ini, proses pengeringan kerupuk masih melalui proses penjemuran dengan sinar matahari langsung. Ketika tidak ada sinar matahari, maka proses pengeringan tidak dapat dilakukan. Apabila terlanjur dijemur, kemungkinan besar adonan 
akan terkena jamur. Dengan alat/mesin pengering diharapkan dapat membantu proses pengeringan kerupuk yang tidak mengenal cuaca.

Kemasan produk kerupuk ubi ungu saat ini hanya mengunakan plastic 1 ball dan kemasan plastic $1 \mathrm{~kg}$ (isi $250 \mathrm{~g}$ ). pada kemasan tersebut tidak terdapat label atau sejenisnya. Pada program pengabdian ini, akan lebih difokuskan untuk membantu mendesain kemasan yang lebih menarik. Dengan penggunaan kemasan diharapkan dapat membantu menarik perhatian konsumen dan membantu proses pemasaran. Selain itu, dari sisi pemasaran akan kami bantu dengan membuatkan sebuah website khusus untuk kelompok wanita Padahanten. Website tersebut tidak dikhususkan untuk kerupuk ubi ungu saja, karena kelompok tersebut tidak memproduksi kerupuk ubi saja akan tetapi banya jenis makanan yang dibuat.

4. Perencanaan desain kemasan

Desain kemasan yang kami tawarkan terdapat beberapa model gambar, diantaranya seperti pada gambar 5 .

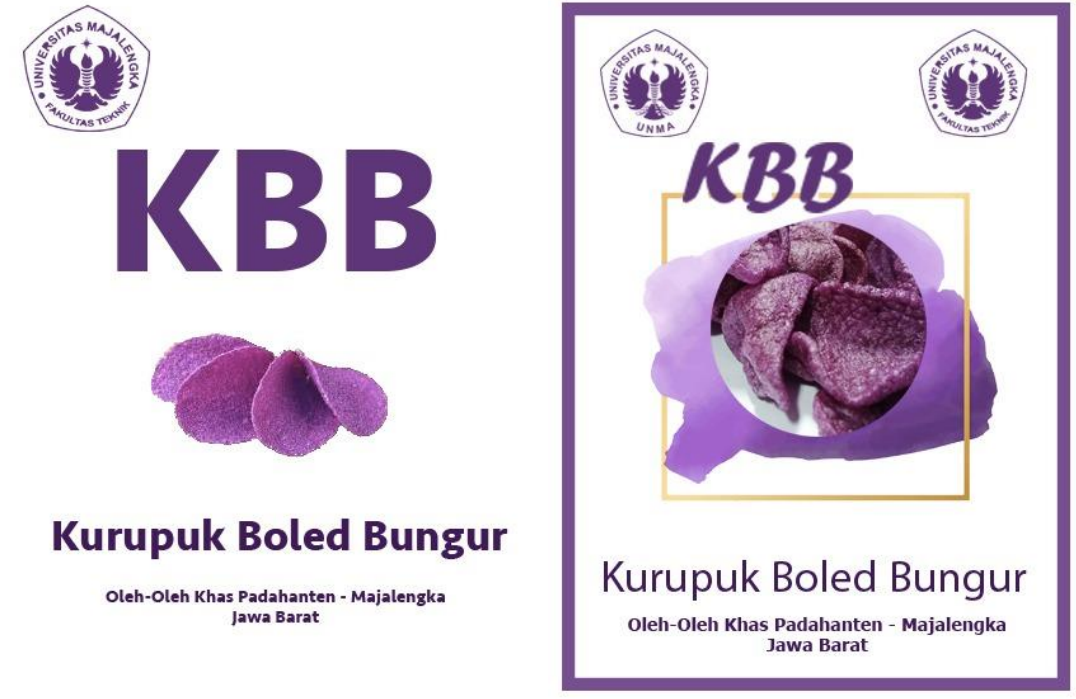

Gambar 5. Desain kemasan kerupuk ubi ungu

Selain dari gambar/logo kemasan, kami juga memberikan beberapa alternative jenis kemasan yang dapat digunakan. Diantaranya seperti gambar 6 .

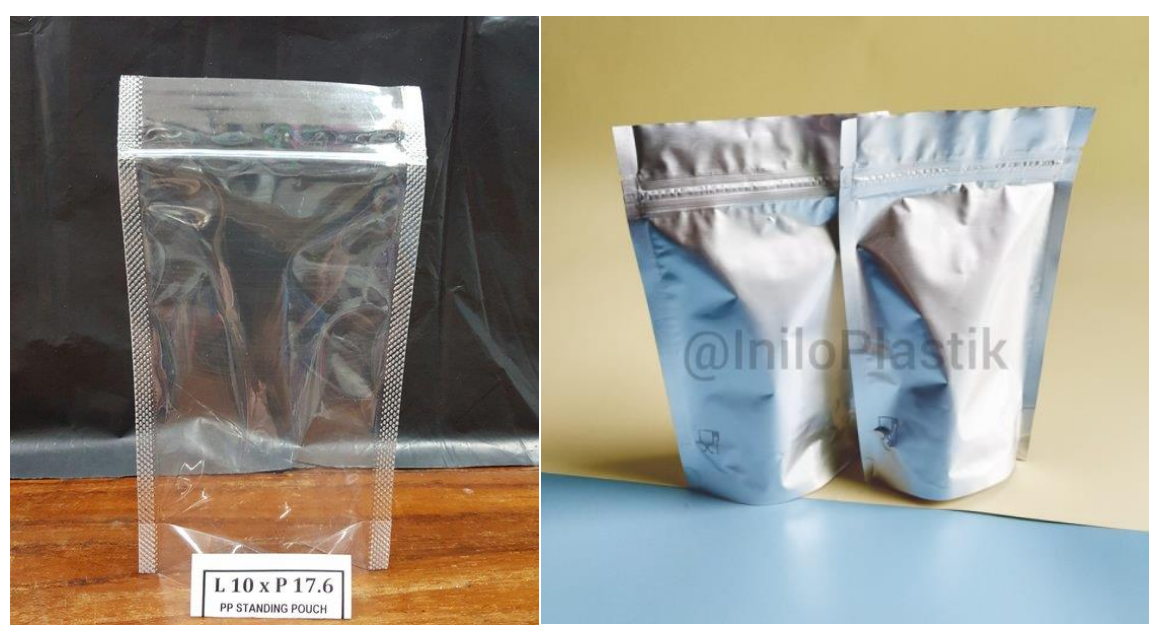

Gambar 5. Bungkus kemasan kerupuk ubi ungu 
5. Perencanaan web pemasaran

Untuk pembuatan website pemasaran, kami menggunakan wordpress. Untuk website pemasaran tidak berfokus untuk produk kerupuk ubi ungu, karena di kelompok tersebut tidak hanya memproduksi kerupuk ubi ungu. Berikut merupakan tampilan dari website https://padahanten.com/
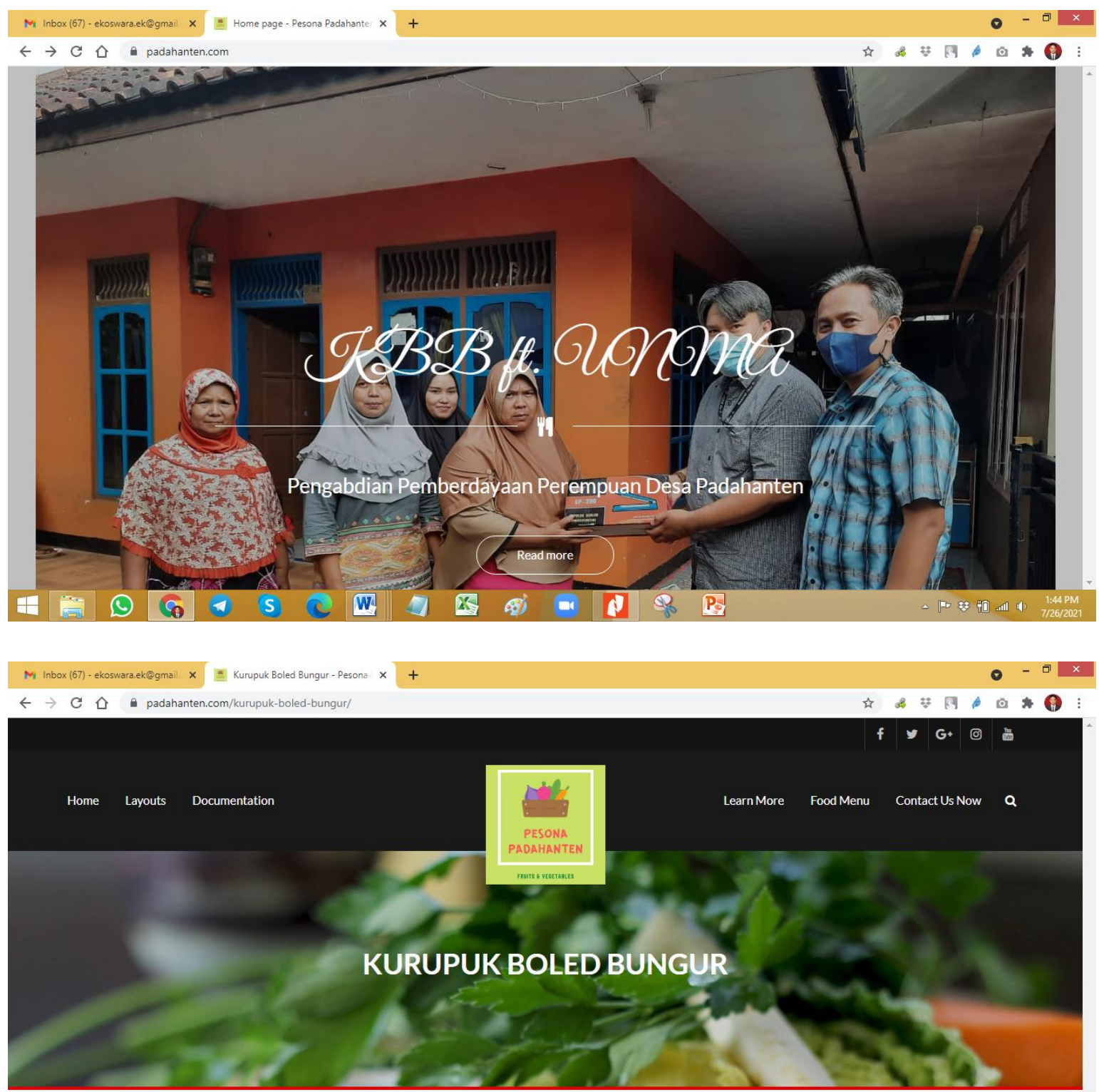

Gambar 6. Website pemasaran 


\section{Kesimpulan}

Hasil pengabdian yang telah dilaksanakan terdapat beberapa hal yang dapat kami simpulkan. Diantaranya kelompok wanita padahanten khususnya pembuat kerupuk ubi ungu dapat mengaplikasikan metode pemasaran dengan menggunakan kemasan yang yang lebih menarik dari sebelumnya. Selain itu, kelompok juga dibekali tata cara penggunaan perekat plastic untuk pembuatan kemasan yang dulunya hanya menggunakan api lilin sebagai perekat.

\section{Ucapan Terima Kasih}

Pemberian penghargaan yang setinggi-tingginya dan ucapan terima kasih kepada Universitas Majalengka melalui P3M sesuai dengan perjanjian Penugasan Program Pengabdian Internal Universitas Majalengka Tahun 2020.

\section{Daftar Pustaka}

Cenadi, C.S., (2004). Peranan desain kemasan dalam dunia pemasaran. Nirmana, 2(2).

Siswanto, T., (2013). Optimalisasi sosial media sebagai media pemasaran usaha kecil menengah. Jurnal Liquidity, 2(1), pp.80-86. 